\title{
ECONOMIC DISINTEGRATION OF THE EUROPEAN UNION: NOT UNAVOIDABLE, BUT PROBABLE
}

\author{
Leon PODKAMINER
}

It is argued that European integration has not fulfilled its chief economic promises. Output growth has been increasingly weak and unstable. Productivity growth has been following a decreasing trend. Income inequalities, both within and between the EU member states, have been rising. This sorry state of affairs is likely to continue - and likely to precipitate further exits, or eventually, the dissolution of the Union. However, this outcome is not unavoidable. A better integration in the EU is possible, at least in theory. Also, the negative consequences implicit in the existence of the common currency could be neutralised. However, the basic paradigms of the economic policies to be followed in the EU would have to be radically changed. First, the unconditional fiscal consolidation provisions still in force would have to be repelled. Second, "beggar-thy-neighbour" (or mercantilist) wage policies would have to be "outlawed".

JEL classification indices: F15, F43, E62

Keywords: European Union, integration, disintegration, economic growth, productivity, race to the bottom

Leon Podkaminer, Senior economist at The Vienna Institute for International Economic Studies. E-mail: podkaminer@wiiw.ac.at 


\section{ECONOMIC INTEGRATION HAS NOT FULFILLED ITS PROMISES}

Under the provisions of the Maastricht Treaty, European economic integration has been further advanced. The introduction of the euro crowned the process of the internal liberalisation of trade within the EU and facilitated the creation of an area of ever freer movements of capital, labour, and services throughout the continent. There are many possible measures of advances in economic integration. Perhaps the most unproblematic of these measures is the share of mutual trade in the EU aggregate GDP. Figure 1 shows the mutual exports as a percentage of euro area (EU-12) GDP since 1960.

Economic integration (just as internal economic liberalisation or globalisation) is generally assumed to be conducive to economic growth (even if it is now often admitted that it may have unwelcome - but transient - distributional effects). Tighter integration has been expected to promote faster overall productivity growth, for example through increased competition and more efficient utilisation of scarce resources.

The European integration has failed to deliver on these promises. Economic growth has been slowing down secularly, since approximately the mid-1970s (Figure 2). Growth rates follow a declining trend, which - if continued - would push the EU-12 into permanent recession. In addition, growth has become increasingly volatile, with violent ups and downs, and recessions climaxing around 1993, 2003, 2009, and 2012. One may bear in mind that the short-lived recessions in 1975 and 1981 could have been the aftermaths of the oil embargoes $(1974,1979)$ and the associated shortages severely affecting the "supply side". Beyond such shortages materially affecting production, the oil shocks had negative consequences for inflation, income distribution, and - especially - private investment. ${ }^{1}$

The deep slumps in 1993 and 2009 cannot yet be viewed as "exogenous shocks". These slumps were "endogenous". They were the consequences of the economic "architecture" consciously designed by the European economic elites. In 1993, the recession was the consequence of the crash of the Exchange Rate Mechanism; in 2009, it was the near-collapse of the EU's financial sector operating by the rules enacted by the EU policy-makers. It may be added that the second-dip recession of 2012 was provoked by the "fiscal consolidation" hys-

Actions by the OPEC cartel produced fundamental uncertainty: would the energy prices/ supplies be allowed to return to "normal" levels, or would they rather stay at "abnormal" levels more or less indefinitely? Under such uncertainty, the best approach to taking (irreversible) investment decisions (involving technology choice: energy saving, or traditional) could be of a wait-and-see sort. 


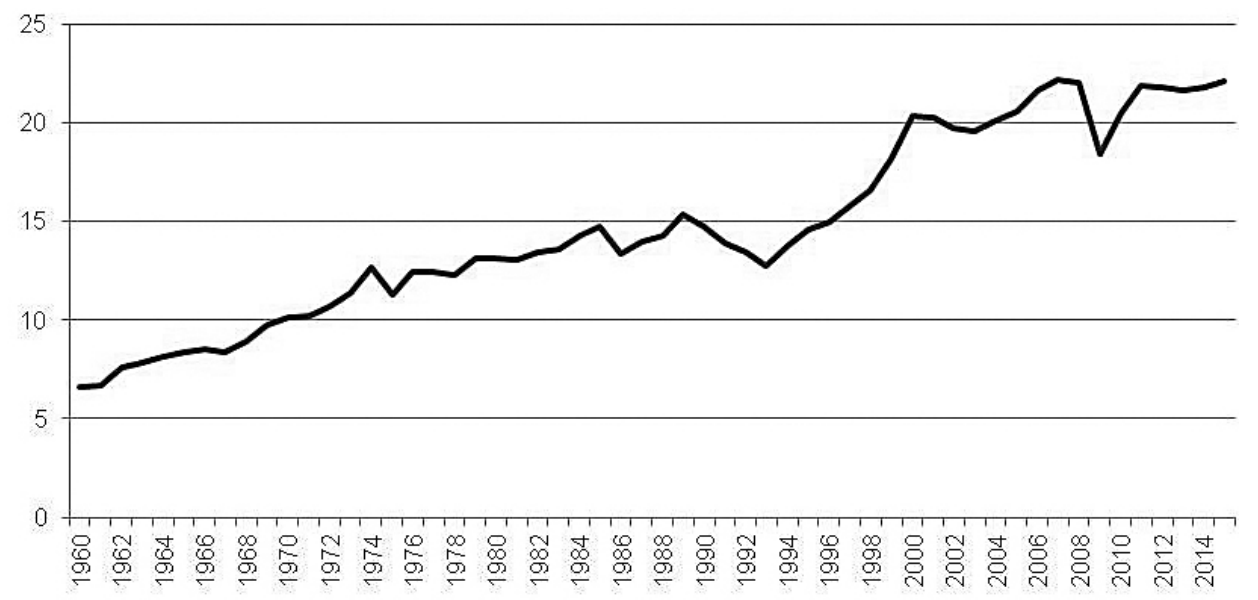

Figure 1. Intra-EU exports as a percentage of EU-12 GDP

Source: AMECO.

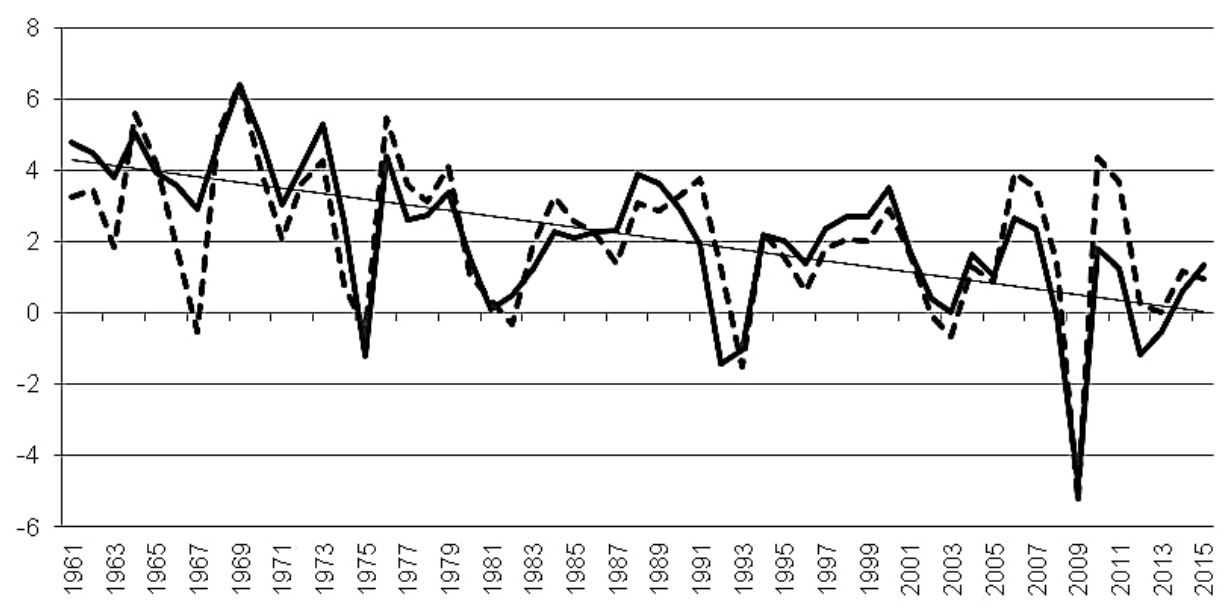

Figure 2. Growth rates of real per capita GDP for EU-12 and Germany

Source: Own calculations based on AMECO, item RVGDP. 
teria gripping the euro area decision-makers. Finally, it is worth observing that the introduction of the euro (since 1998) and the full internal trade liberalisation (Single European Market, since 1993) did nothing to accelerate and smooth out GDP growth.

\section{Is the weakening labour productivity growth responsible for the slowdown} of output growth?

Labour productivity has also followed a declining trend (Figure 3). This outcome is usually considered a paradox. A number of commentators and researchers have pondered on the ongoing productivity growth slowdown. Given the (apparent) acceleration of technological progress and the rather obvious advances in applied research and innovation activities, the labour productivity growth slowdown is considered a paradox. The solutions to the paradox sometimes forwarded suggest that output (and productivity) have been systematically underestimated by the statistics (e.g. Mokyr 2014, or Feldstein 2015). Others tend to disagree with the mismeasurement thesis without yet offering a coherent explanation of the paradox (e.g. Byrne et al. 2016).

Gordon (2015) is the most vocal representative of the "supply-siders" who suggest that the technological progress has not prevented the weakening of labour productivity growth. He then goes as far as to blame the post-2008 stagnation itself on the slower growth (since 2004) in potential output "emanating from the

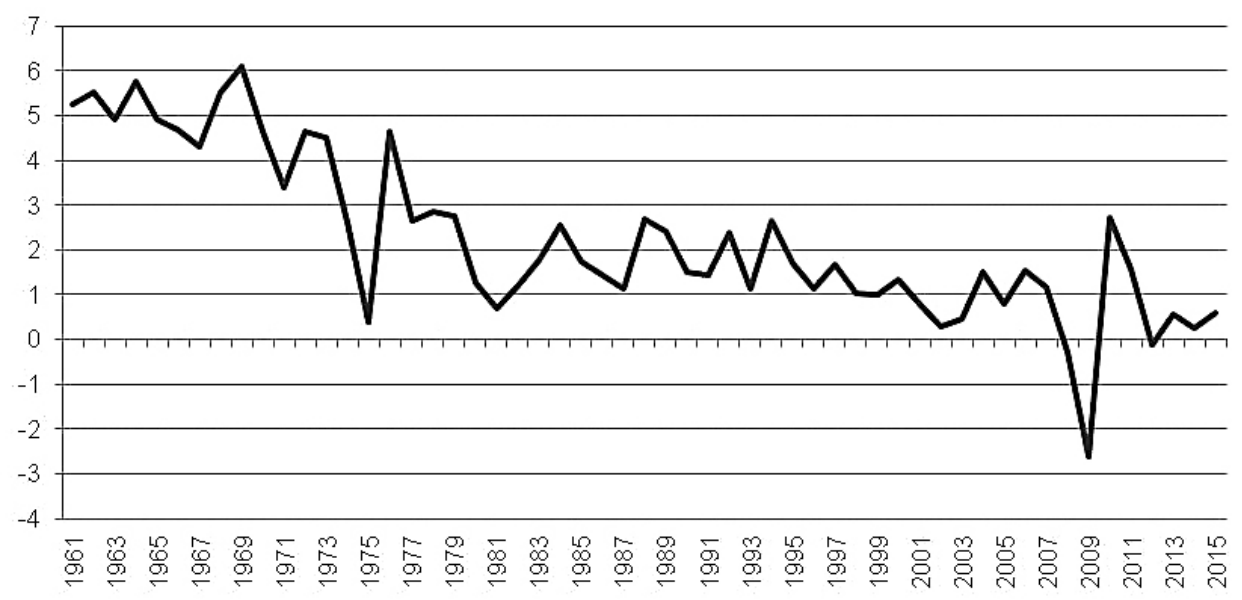

Figure 3. Real productivity (GDP per employed person) growth rate for EU-12

Source: AMECO. 
behaviour of productivity". The implication of this seems to be that the supply side needs further "structural reforms", stronger deregulation, more labour market flexibility, etc., so as to strengthen productivity growth and thus contribute to the faster growth of output.

However, the results of an econometric examination of the links between labour productivity and output growth for 22 countries (for which long-term data are available), for West Germany (years 1960 through 1991), for unified Germany (years 1991-2015), and also for a larger set of countries (years 1991, or 1995 , through 2015) indicate that, generally, productivity does not "cause" output (Podkaminer 2016). Much more often, the causation seems to be running in the opposite direction: from output (or its growth rate) to productivity (or its growth rate). This finding, though inconsistent with the "mainstream" ideas on the sources of long-term economic growth, is reminiscent of the classical Kaldor - Verdoorn Law (Kaldor 1966). The progressing slowdown in output growth at the global level, initiated in the mid-1970s (amid the wholesale change of economic policy paradigms), may have been mirrored - and followed - by the progressive slowdown in productivity growth (and that despite the indisputable acceleration of technological progress). Productivity growth slowdown cannot be the cause of the overall slowdown of output growth in the EU.

\section{Is an excessive degree of income redistribution the problem?}

Can it be that productivity and output growth slowdown has been the price for increased income convergence - greater income equality? The answer is no. The dispersion of per capita incomes across the EU member states has been increasing (Figure 4). One observes sigma-divergence instead of sigma-convergence. In terms of per capita income, the "old" EU has shown divergence rather than convergence (excluding a brief period of the recession-related income convergence in 2009). The same is true for the extended EU.

The increase in income inequality has been even more pronounced in individual EU member states: "It is the within-country, not the between-country dimension, which appears to be most important. Inequality in Europe has risen quite substantially since the mid 1980s" (Bonesmo Fredriksen 2012: 2). ${ }^{2}$

2 It is rather obvious that the growth slowdown cannot be attributed to the intensified shortages of labour: unemployment has been high since the early 1980s. Neither can it be attributed to intensified shortages of exhaustible natural resources. The continuing secular decline in commodities' terms-of-trade indicates that commodities are becoming less scarce, not more (see e.g. Mollick et al. 2008). 


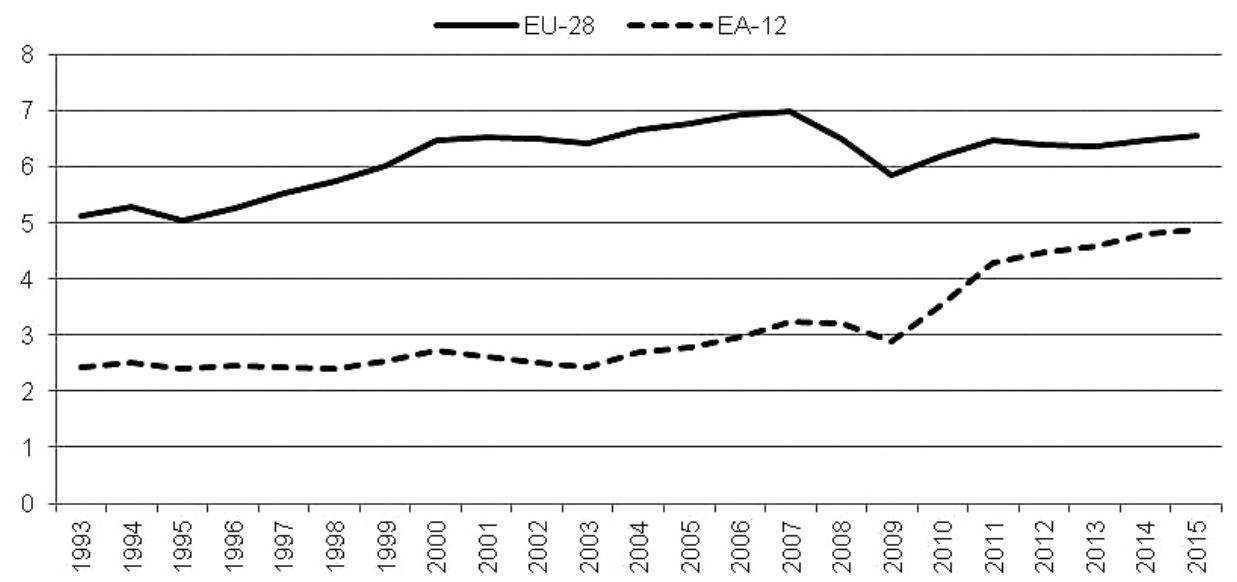

Figure 4. Standard deviation of per capita gross national income (in 1000 PPS), population-weighted

Source: Own calculations based on AMECO (item HVGNP).

Note: $\mathrm{EA}=$ Euro Area (12 countries).

\section{Central and East European new member states: trapped in integration}

The economic history of the Central and East European new member states of EU is still quite short. Nonetheless, the economic growth of these countries - under progressing integration into the EU - is not really impressive. The post-accession boom (2003 through 2007) was fairly short and ended in deep recession (Figure 5). The post-recession growth has been anaemic. There are good reasons to expect their growth to be rather slow in the future (Podkaminer 2015a). These countries have come to depend, economically, on the West European core (primarily Germany). The pace (and sources) of their economic growth have been adjusting to those of Germany. In the medium term, they will not grow much faster than Germany - and the German economy is very likely to stagnate.

\section{THE REASONS OF THE FAILURE}

For some authors, the economic failure of the EU can be directly attributed to the principles first introduced in the Maastricht Treaty and later reiterated in a series of fiscal compacts or pacts. Combined with the common currency (and the common monetary policy embodying the tradition of German central banking), the Maastricht fiscal rules have eventually suppressed output growth, generated 


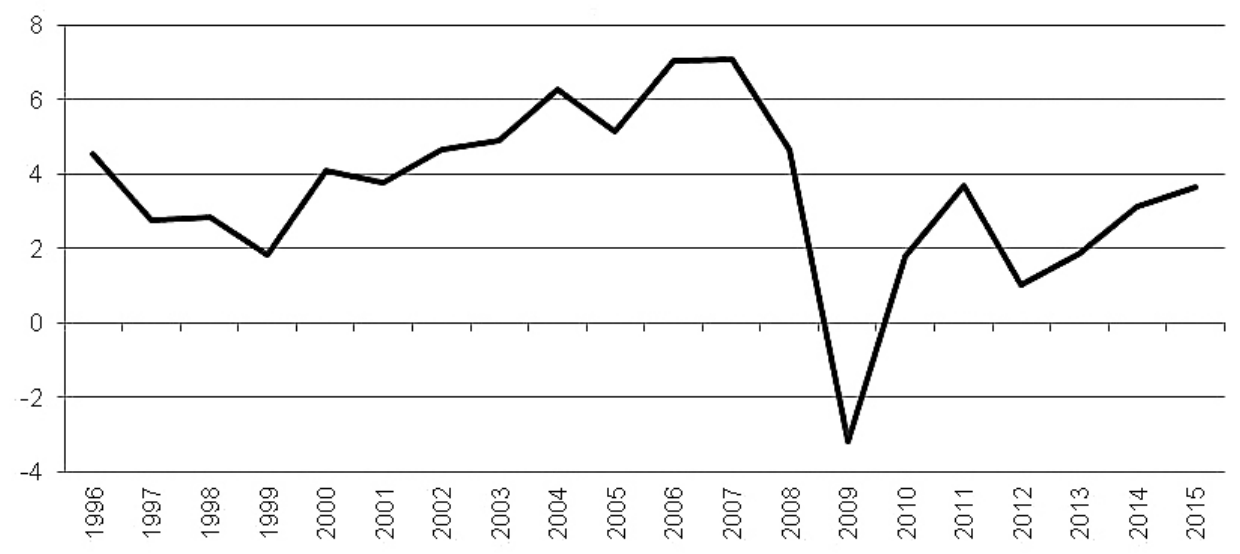

Figure 5. Real rates of growth of output per capita for the 10 NMS

Source: Own calculations based on AMECO, item RVGDP.

internal imbalances - and thus paved the ground for the internal economic disintegration of the Union (Laski - Podkaminer 2012).

The vicious dynamics behind the developing economic drama can be concisely described as follows. First to come is the set of fiscal rules setting narrow limits for public sector deficits. The fiscal rules are to apply universally - without regard for national specificities. Thus a country (such as Germany) which is capable of producing output in excess of the needs of its private sector (be it private consumption or private investment) cannot rely on the public sector to absorb the excess private sector savings by means of deficit spending. It is thus left with no other easy option than to run trade surpluses. For such a country, running trade surpluses becomes a way of supporting domestic growth (and of keeping its own unemployment in check). Of course, for a country to be capable of running trade surpluses there must be some countries capable of running trade deficits. It is understood that for countries running trade deficits this implies not only accumulation of foreign debt - but also the suppression of domestic output growth and additional unemployment (to be associated with persistent fiscal deficits).

At this stage, it is important to consider the way the common currency facilitates the rise of cross-country imbalances. One currency, one monetary policy, and one policy interest rate have very different economic implications for various members of the same group. The policy interest rate has been tuned to the average inflation rate calculated for the whole area. That would be fine if inflation (and inflation histories) were similar across the whole area. But in fact, they are different. In consequence, for countries with inflation persistently higher 


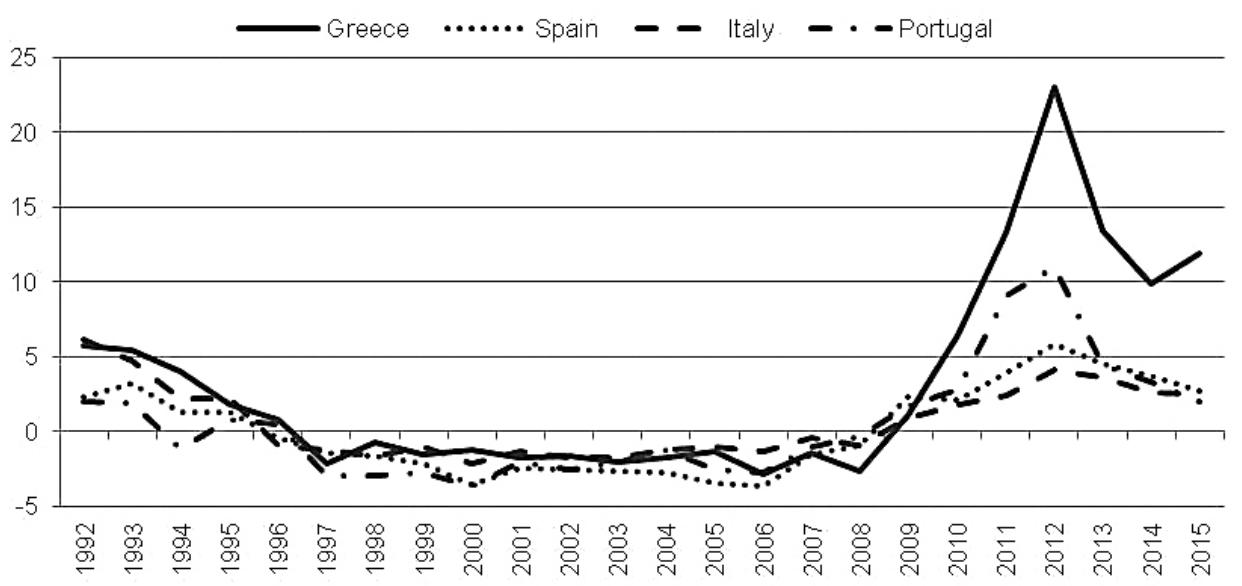

Figure 6. Real long-term interest rates (spread over Germany)

Source: AMECO, item ILRV.

than the average, the real interest rates have tended to be low (or even negative) while - at the same time - the real interest rates may be prohibitively high in countries with much lower inflation. As Figure 6 shows, until 2008, the real interest rates in Germany were consistently higher than elsewhere. Of course, such differential developments favouring Germany's partners could not persist indefinitely. As soon as the boom supported by low real interest rates collapsed (under the weight of accumulated domestic and foreign debts), the real interest rates in countries that had higher inflation became high (in many cases excessively high). It is at this stage that the initial boom turned into recession.

The moral to this story is that the principle "one size fits all" does not work in practice. The common monetary policy has been destabilising growth and inflation: strengthening inflation (and growth) in countries experiencing a boom, while suppressing inflation (and growth) in countries experiencing deflation and output slump. Importantly, as the consequence of differential developments in real interest rates (and inflation), the countries with traditionally low inflation (and, consequently, weak growth in wages (such as Germany) have been gaining cost-competitiveness advantages vs. their higher-inflation partners (Figure 7).

That way the low-inflation (and weak-growth) countries have become reliant on ever rising trade surpluses - while the higher-inflation countries that had earlier priced themselves out of international competition have been forced to reduce their trade deficits (Figure 8) - as a rule goes hand in hand with persisting depression (or even recession). 


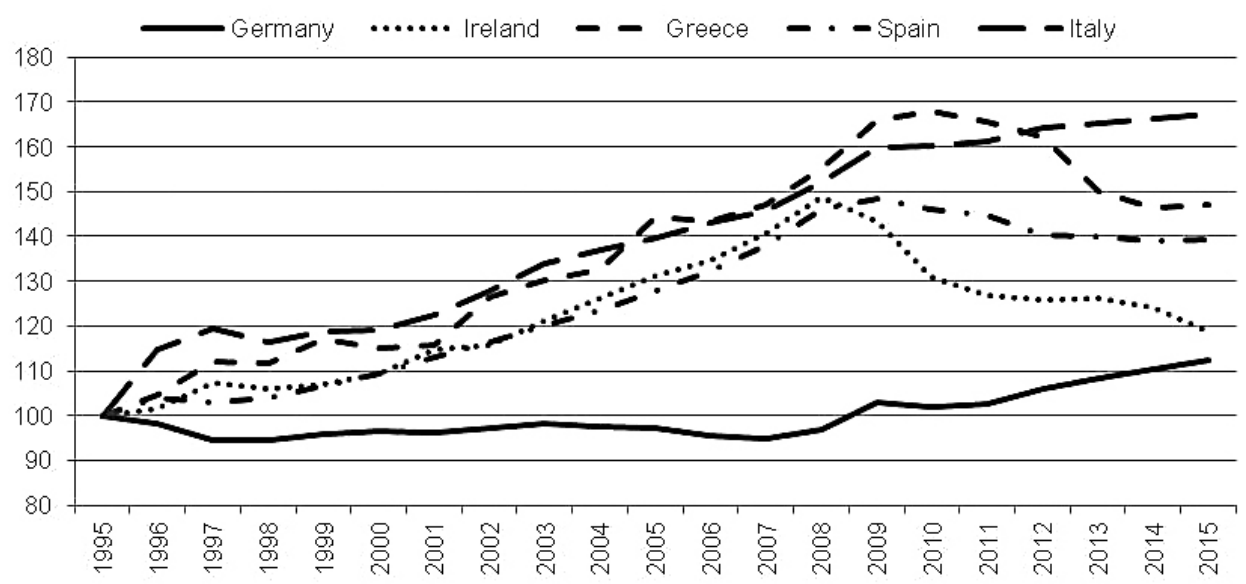

Figure 7. Nominal unit labour costs

Source: AMECO, item PLCD.

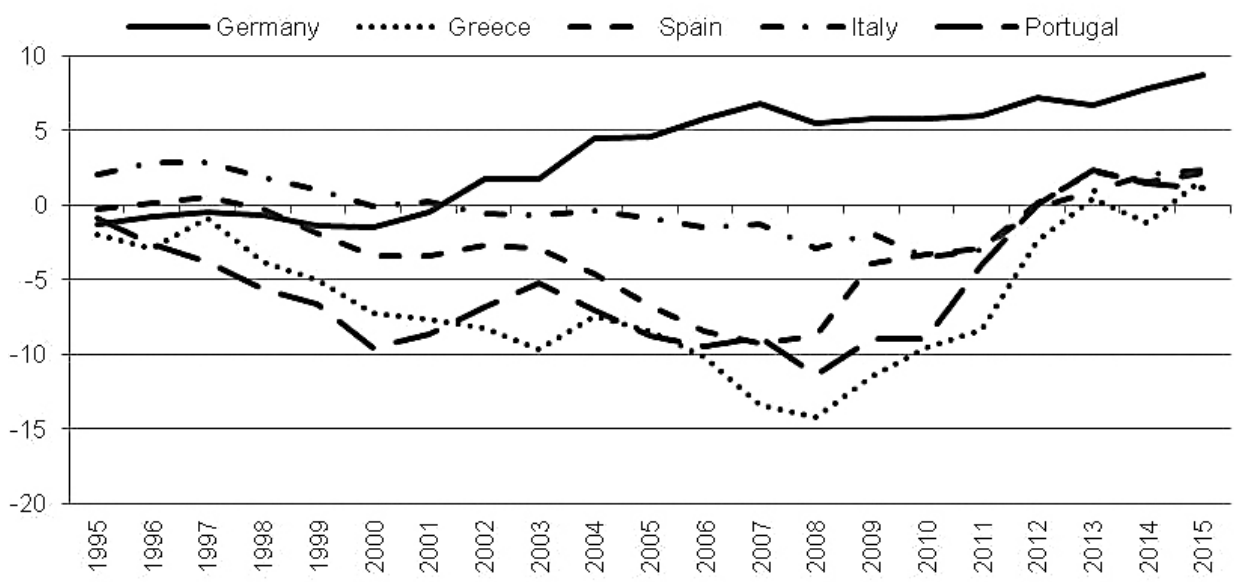

Figure 8. Net external lending as a percentage of GDP

Source: AMECO, item UBLA.

\section{Is a better integration in the $\mathbf{E} \mathrm{U}$ possible?}

A better integration in the EU is possible, at least in theory. Also, the negative consequences implicit in the existence of the common currency could be neutralised. However, the basic paradigms of the economic policies to be followed in the EU would have to be radically changed (Laski - Podkaminer 2012). 
Two closely related aspects are of crucial importance: first, the rejection of the unconditional fiscal consolidation provisions still in force; second, the prohibition of "beggar-thy-neighbour" (or mercantilist) wage policies.

The latter issue is obviously important because unduly restrictive wage policies which consequently lead to large trade surpluses not only suppress growth in countries which fail to follow suit (and thus run trade deficits and accumulate foreign debts), but also because the suppressed wages (as e.g. in Germany or Austria) are responsible for overall weak growth in countries implementing the internal "wage moderation" strategy. In practice, the "beggar-thy-neighbour" policy is also a "beggar-thyself" policy (Laski - Podkaminer 2011).

Rejection of the unconditional fiscal consolidation provisions is equally important for countries (again, such as Germany) whose private sector tends, on a permanent basis, to save much in excess of its own investment. Without the ability to run trade surpluses (but which never can be sustained indefinitely), such countries must either experience depression, or allow public sector deficits to absorb the excessive private savings (Laski - Podkaminer 2013).

\section{GLOBALISATION IS NOT HELPFUL}

Sometimes, there have been allusions to the possibility (and even desirability) of each and all EU member states taking over the German economic policy of repressed wages, balanced public finances, and sizeable trade surpluses (necessarily $v s$. the rest of the world). This proposition is an economic mirage if only because it stipulates the existence of a global economy capable of indebting itself to the EU indefinitely. Otherwise, the EU acting internationally as a much greater Germany is unlikely to be accepted by the United States. Very likely, the latter country would retaliate in kind, or adopt protectionist measures. Besides, the economic strategy relying on repressed wages (and thus repressed domestic demand) guarantees weak overall output growth (as the bulk of GDP consists of non-tradable domestically produced goods and services).

Expectation that the outside world - especially in the conditions of advancing globalisation - is somehow capable of helping the European integration is not well grounded. In actual fact, the whole global economy is suffering from a malaise that is not very much different from the one affecting Europe. Progressing globalisation turns out to have been associated with the growth of global output becoming progressively weaker and more unstable (Figure 9).

Expanding world trade has failed to accelerate global growth. Rather, the expanding trade may be argued to have contributed to the output growth slowdown (Podkaminer 2014). The possible reasons for the unexpected (but econometrical- 


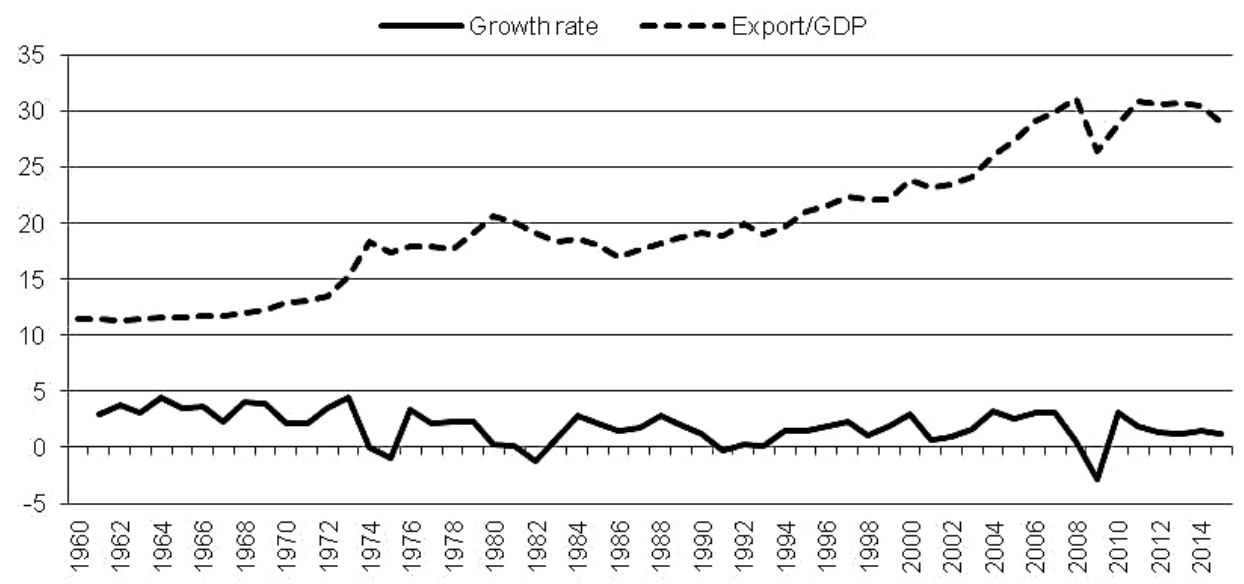

Figure 9. Global exports/GDP share and the growth rate of global GDP per capita

Source: WDI, items SL.GDP.PCAP.EM.KD and NE.EXP.GNFS.CD.

ly well-grounded) conclusions are partly similar as in the EU's case. First, under progressing capital account liberalisation individual countries are quite likely to run trade surpluses (or deficits) much longer than would be possible under less free capital movements. This makes the growth process much more unstable. Second, under progressing trade liberalisation, there is a tendency for countries to engage in wage and tax competition. Individual countries try to outsmart the competitors. But when all engage in the race to the bottom, no-one is going to win - and all are likely to lose.

\section{CONCLUDING REMARK}

The existence of the European Union is of vital importance to the Europeans and especially for the Central and East European countries. Without the EU, these nations would once again find themselves alone, in a grey zone between their all too mighty neighbours.

But the EU cannot prosper within the confines of self-imposed limitations that have little economic justification, theoretical and practical. Unless the basic paradigms of economic policy for the EU are overhauled, the EU will remain a stagnant area convulsed by recurring economic (and then social and political) crises. Sooner or later, these crises will give rise to further exits or would even precipitate the dissolution of the Union. 
Whether the radical change happens before it is too late is of course highly uncertain. In any case, it should be the duty of Central and East European politicians - and also economists - to voice their concerns over the overall orientation of the economic policies of the European Union.

\section{REFERENCES}

Bonesmo Fredriksen, K. (2012): Income Inequality in the European Union. OECD Economics Department, Working Paper, No. 952.

Byrne, D. J. - Fernald, J. G. - Reinsdorf, M. B. (2016): Does the United States have a Productivity Slowdown or a Measurement Problem? Brookings Papers on Economic Activity, Conference Draft, March 10--11.

Feldstein, M. (2015): The U.S. Underestimates Growth. Wall Street Journal, May 18.

Gordon, J. R. (2015): Secular Stagnation: A Supply-Side View. American Economic Review: Papers \& Proceedings, 105(5): 54-59.

Kaldor, N. (1966): Causes of the Slow Rate of Economic Growth in the United Kingdom. Cambridge: Cambridge University Press.

Laski, K. - Podkaminer, L. (2011): Common Monetary Policy with Uncommon Wage Policies: Centrifugal Forces Tearing the Euro Area Apart. Intervention. European Journal of Economics and Economic Policies, 8(1): 21-29.

Laski, K. - Podkaminer, L. (2012): The Basic Paradigms of EU Economic Policy Making Need to be Changed. Cambridge Journal of Economics, 36(1): 253-270.

Laski, K. - Podkaminer, L. (2013): Net Private Savings in Relation to the Government's Financial Balance: Some Basic Principles of Macroeconomics Disregarded by the European Union's Economic Policy Makers. In: Dejuán, Ó. - Febrero, E. - Uxó, J. (eds): Post-Keynesian Views of the Crisis and its Remedies. London: Routledge

Mollick, A. V. - Faria, J. - Albuquerque, P. - Leon-Ledesma, M. (2008): Can Globalisation Stop the Decline in Commodities 'Terms of Trade'? Cambridge Journal of Economics, 32(5): 683-701.

Mokyr, J. (2014): Secular Stagnation? Not in Your Life. In: Teulings, C. - Baldwin, R. (eds): Secular Stagnation: Facts, Causes, and Cures. VoxEU.org eBook.

Podkaminer, L. (2014): Does Trade Drive Global Output Growth? Bank \& Credit, 45(4): 311330.

Podkaminer, L. (2015a): The Euro Area's Secular Stagnation and what can be Done about it. A Post-Keynesian Perspective. Real World Economics Review, Issue 70: 1-16.

Podkaminer, L. (2015b): Central Europe: Trapped in Integration? Acta Oeconomica, 65 (S 1): 83106.

Podkaminer, L. (2016): The Slowdown in Labor Productivity Growth is an Effect of Economic Stagnation rather than its Cause. Presentation at the "Economic Growth and Social Equity - Conference on Nicholas Kaldor's Legacy in the 21st Century", organised by Corvinus University Budapest and Fridrich Ebert Stiftung, Budapest, September 30. 